\title{
THE TEST OF IMPLICIT ATTITUDES TOWARDS PERSONS WITH VISUAL, INTELLECTUAL AND MOTOR DISABILITIES (IAT-VIMD): A PRELIMINARY STUDY
}

\author{
Paweł Kurtek \\ Department of Psychology, Jan Kochanowski University in Kielce
}

\begin{abstract}
The implicit attitudes, compared to explicit attitudes moderated by social pressure, play a dominant role in everyday interactions with disabled persons. Therefore, the purpose of the paper is to present the development of Implicit Attitudes Test toward Persons with Visual, Intellectual, and Motor Disabilities (IAT-VIMD). It has been developed to compare the favorization vs devaluation tendency towards non-disabled and disabled adults. We applied photographs showing people in everyday situations to assure spontaneous reactions of the respondents. Ninety-two respondents aged 19-22 years took part in the research. The procedure is based on the IAT (Implicit Association Test) index, developed by Greenwald, McGhee, \& Schwartz(1998), i.e. the difference in response time to affective compatible vs non-compatible signals. Statistical analysis confirmed the content validity based on the Competent Judges' agreement as regards the type of disability, the level of visibility and the level of overall life activity of the object. The external validity was verified with The Conditional Respect for Persons with Disabilities Questionnaire (CRPD-Q) by Kurtek (2018). Next the absolute stability of the test was proved. The presented IAT-VIMD meets the psychometric criteria of content and theoretical validity as well as reliability, and has the potential to become a useful measure of implicit attitudes towards adults with visual, motor and intellectual disabilities in various social groups. The discussion points to the test's limitations and recommendations for future development and use. In particular, a need for further research on the external validity of the test has been emphasized.
\end{abstract}

Keywords: Implicit Association Test; social cognition; dual attitudes; social attitudes towards disabled persons.

PAwEe KuRTeK, https://orcid.org/0000-0003-2149-6175. Correspondence concerning this article can be addressed to Pawet KuRTeK, Wydział Pedagogiki i Psychologii, Uniwersytet Jana Kochanowskiego w Kielcach, ul. Krakowska 11, 25-029 Kielce, Poland; e-mail: kurtekp@ujk.edu.pl.

Handling editor: KAMIL IMBIR, University of Warsaw.

Received 20 May 2020. Received in revised form 11 Feb. 2021. Accepted 4 May 2021. Published online 12 July 2021. 
An attitude is a relatively stable tendency of the subject to affectively evaluate an object (Wojciszke, 2005). An attitude is formed only towards objects that are the goals of motivated behavior, and are, therefore, important in gratifying an individual's needs (Wyczesany \& Gajdzica, 2006). Groups of disabled people, whose perceptual, intellectual, and motor functions are impaired, may constitute a central or peripheral cognitive-evaluation object, depending on the degree in which they may satisfy or frustrate the subject's needs. However, it can be assumed that due to a significant percentage of adult disabled people in Polish society, i.e. around $10 \%$ in 2018 (information retrieved from the Office of the Government Plenipotentiary for Disabled People), nondisabled people, who have various relationships with the disabled, form their own attitudes towards them. In accordance with the Social Labelling Theory, attitudes expressed towards people with disabilities are crucial for the rehabilitation process (Kowalik, 2007; Minczakiewicz, 1996; Siegert \& Taylor, 2004). They are a direct signal of encouragement or threat, a sign that someone is offering support or expressing reproach, an indication of success or disappointment, acceptance, or rejection, etc. Indirectly, in turn, attitudes influence the process and effects of rehabilitation by forming the disabled persons' personality, which is a complex mechanism of the interpretation and regulation of behavior (Larkowa, 1980). Thus, the diagnosis of social attitudes, especially of significant persons and groups in crucial development periods, towards disabled individuals can help explain and predict rehabilitation processes.

Social attitudes are a key element of an interaction between partners i.e. the subject and the object of an interaction. Taking into account the complex character of attitudes, we can analyze various aspects that are activated within the acting subject (e.g. beliefs, feelings, behavioral tendencies, evaluations, motives) and the experiencing object (e.g. intrapsychic experiences, attributions, and observable and unobservable responses to the subject's attitude). Until now, it has been assumed that cognitive, affective, and behavioral aspects of an attitude presented by the subject are compatible with each other; yet, many empirical reports indicate that they are separate units, especially a cognitive and a behavioral one (Larkowa, 1980; Sękowski, 2001). The lack of compatibility of attitudes may have grounds in current social trends and individual factors.

The current optimism for the normalization of the living conditions of people with disabilities and social integration in school, professional or local environments, initiated in the 1980s, is now experiencing a crisis in many European countries (Speck, 2012). It is associated with lower dynamics of economic growth, demographic changes such as an increase in the number of dependent people, i.e. the disabled and the elderly, as well as a limited rate of return on investment on special education and supported forms of employment. In this context, a utilitarian-com- 
petitive model of social relations is formed, in which a person with a disability more than a nondisabled person is likely to experience a failure, and consequently negative evaluation and marginalization. On the other hand, social and educational policy promotes the value of social solidarity and the idea of subsidiarity towards dependent people. The resulting economic and ethical conflict may lead to a breakdown of the internal coherence of attitudes towards disabled persons in the form of a discrepancy between their explicit and implicit dimensions. In addition to the social context, intrapsychic mechanisms also play an important role in shaping attitudes towards disabled individuals. For example, according to the Concept of Ambivalent Attitudes by Anthony (1977), a disabled person evokes contradictory, both positive and negative emotions, which may be related to different aspects of their functioning. For example, while compassion may arise from the conviction about the harm suffered by these people, hostility may be connected with the belief that disabled people are irresponsible or demanding. Though positive and negative emotions are often mutually excluded, according to the Evaluative Space Model (Larsen et al., 2001), the contradictory feelings may co-occur in emotionally complex situations. Therefore, a relation with disabled persons may raise ambivalent emotions that are activated separately or simultaneously.

Whether positive or negative emotions appear depends on the dynamics of situational factors and the individual's mechanisms (e.g. aggression displacement, need to improve one's self-esteem, or searching for a scapegoat; see Kowalik, 1999).

People with disabilities are, therefore, evaluated based on diverse cultural and personal criteria, which may result in a discrepancy between the explicit and implicit dimensions of an attitude (Chen et al., 2011; Vaughn et al., 2011). According to the concept of Implicit Social Cognition by Greenwald and Banaji (1996), implicit attitudes are unidentified (or incorrectly identified) traces of past individual experience that may affect behavior. This concept refers to a dual attitudes model, according to which both systems of an attitude (explicit and implicit) are relatively independent. While implicit attitudes are based on quick, automatic mechanisms of cognition and emotional stimulation, explicit attitudes, on the contrary, are grounded in slow, conscious mechanisms of cognitive reasoning and evaluation (Chaiken \& Trope, 1999; Wilson et al., 2000; Domasio, 2010).

Therefore, the dual attitudes model suits the general duality of mind approach, stressing the automatic vs controlling mode of the information processing (Kahneman, 2011; Imbir, 2018). According to the concept of dual attitudes, a person's lack of awareness of their implicit attitude (therefore the separation of the systems) is based on the mechanisms of repression or splitting (Wilson et al., 2004). The activation of the mechanism of repression assumes the pre-existence of an implicit attitude (expressing tendencies unaccepted by the individual) before an explicit 
attitude. In the case of the mechanism of "splitting," both systems can be activated in different contexts: explicit in controllable, while implicit in spontaneous situations. Then, a discrepancy between both systems does not result from the repression of the content threatening to the "ego," but from the lack of motivation to become aware of one's original tendencies. This does not mean, however, that an implicit attitude must always be contradictory to an explicit one. The studies show an interaction between explicit and implicit attitudes (Maison, 2004). If an individual becomes aware of their implicit attitude, there may start a process of a conscious "replacement" when new conscious assessments simultaneously lead to the creation of alternative affective associations (Whitfiled \& Jordan, 2009). On the other hand, if an implicit attitude comes to the surface, an explicit attitude may become adjusted to unconscious tendencies based on the rationalization process. The coherence of both dimensions allows minimization of the discomfort caused by a cognitive dissonance (Festiger, 2017).

So far, the examination of implicit attitudes has been carried out using different methods such as the Adjective Evaluation Task (Fazio et al., 1986), the Lexical Decision Task (Wittenbrink et al. 1997) and the Implicit Association Test (Greenwald et al., 1998), which gained the most popularity. The IAT technique was used to analyze prejudices against various social groups, such as: Asians, obese people (Rudman et al., 2002), or homosexual people (Banse et al., 2001). It was also used to study implicit consumer attitudes (Maison, 2004; Maison et al., 2004), attitudes towards oneself (Greenwald \& Farnham, 2000), and eventually, to assess the associations with disabled (Pruett \& Chan, 2006; Thomas et al., 2007). However, the previous computer-based Implicit Association Tests use words as representing different types of disabilities. Therefore, we decided to develop the IAT materials in natural graphical code which better represents the introspectively unidentified or inaccurately identified traces of past experience (Greenwald \& Banaji; 1996). The lack of a tool on the Polish market using the IAT procedure to study implicit attitudes towards disabled people motivated us to create such a test. Questionnaires which prevail on the Polish market focus on a declarative aspect of attitudes towards people with disabilities, ignoring their hidden or unconscious aspects. ${ }^{1}$ While the declared views in Polish population are usually positive, emotions and behaviors targeted at people with disabilities are rather negative (Ćwirynkało, 2010; Nowak, 2015; Sękowski,

${ }^{1}$ An example of such tools is the Scale of Attitudes Towards the Disabled (PWON) by Andrzej Sękowski (1994), based on the cognitive dissonance theory (the bigger the difference between the image of a nondisabled and a disabled person, the more negative attitude towards the latter). Similarly, Gajdzica's tool based on the theory of Social Distance, makes it possible to measure a tendency to engage in relationships of varying degrees of intimacy with disabled persons. 
2001; Zasępa, 1998). Some results of empirical research indicate stronger relationships of unconscious rather than overt attitudes with the behavior towards disabled people, as unconscious attitudes in the form of stereotypes or prejudices are more internalized and fixed in nature (Speck, 2012). Compared to explicit attitudes, implicit attitudes to a larger degree explain behaviors occurring in natural conditions, poorly controlled for the subject or when they concern socially sensitive issues (Maison, 2004; Fazio, et al., 1986). The knowledge about the implicit dimension of attitudes towards those who are disabled may be crucial in understanding emotional attitudes and behavior towards this social group, especially in natural situational contexts that trigger automatic behavior, such as time pressure or cognitive overload. In addition, the evaluation of people with disabilities is subject to a cognitive bias due to social pressure or the subject's need to preserve an ideal self-image. Therefore, developing a test measuring implicit attitudes towards disabled people seems particularly valuable. The aim of this paper is to present the Implicit Association Test toward persons with Visual, Intellectual, and Motor Disabilities (IAT-VIMD).

\section{METHOD}

\section{Instrument}

The IAT technique measures and compares reaction times in the so-called compatible and noncompatible conditions (Greenwald et al, 1998; Maison, 2004). It is assumed that evaluatively compatible objects receive shorter responding than noncompatible objects, which, due to ambivalence, generate decision-making resistance and a prolonged reaction time. Therefore, faster categorization of a set of positive (pleasant) objects with disabled people compared to nondisabled people and a slower assignment of a set of negative objects to disabled people, compared to a nondisabled group, points to the favoring of people with disabilities or the negative evaluation of nondisabled people. Conversely, faster responding to positive objects with nondisabled people as well as faster responding to negative objects with disabled people, indicates the negative evaluation of people with disabilities or the favoring of nondisabled individuals. The methodology of the procedure (combination of pairs of objects: affective and descriptive), however, does not allow for a determination if differences in response times mean positive affection towards one's own group of reference and resistance to associate it with negative objects (the favoring of one's own group), or, conversely, aversion towards an out-group and resistance to create positive association with it (negative evaluation of others). Thus, 
the technique makes it possible merely to indicate differences in implicit affection for the studied groups. However, it is recognized that the higher the IAT effect index (the difference in reaction times in compatible vs. noncompatible conditions), the greater the likelihood of the occurrence of both processes (Jarymowicz, 1996). In addition, as the process of the favoring of one's "own" group is more universal than discrimination against the "out-group," it is recommended to interpret the IAT effects in terms of favoring one's own group of reference (Jarymowicz, 2006). Such an interpretation, though, seems less relevant in the study of the dynamics of social inclusion processes, which assume the equality of both partners of an interaction.

The IAT procedure uses descriptive and evaluative stimuli in a verbal or pictorial form. In the described IAT-VIMD technique, descriptive objects are adult nondisabled persons and adult people with visual, motor, or intellectual (of a deeper degree) disabilities. Affective positive objects are represented as flowers, while negative objects as insects. Due to visible physical differences between nondisabled and disabled people, and because the majority of daily interactions between these two groups take place via eye contact, a graphical representation of these people in everyday situations was used.

A computerized version of the IAT technique was developed, based on the assignment of randomly appearing objects in the middle of the screen to the relevant category by using a cursor. The test consists of a preliminary part (example) and a main part, based on the categorization of an object into one of two homogeneous sets, and, next, to one of two heterogeneous sets, according to the following research scheme:

1. Sample categorization of the photographs of people to one of two homogeneous sets (Nondisabled vs. Disabled people) — without a time limit.

2. Categorization of 10 pictures of people into the homogeneous sets listed above (with time measurement for tasks 2-6).

3. Categorization of 10 photographs of flowers and insects into two homogeneous sets (Insects vs Flowers).

4. Categorization of 36 objects: nondisabled or disabled people, insects, and flowers ( 9 for each type of object) to one of two heterogeneous sets: Flowers and Nondisabled people vs. Insects and Disabled people (a compatible categorization), preceded by an example.

5. Categorization of 10 objects into one of two homogeneous sets (Nondisabled vs. Disabled) - a task similar to Task 2 but with a reversed location of the sets on the screen to avoid a functional transfer.

6. Categorization of 36 objects: nondisabled or disabled people, insects, and flowers (9 for each type of object) into one of two heterogeneous sets: Flowers 
and Disabled people vs Insects and Nondisabled people (a noncompatible categorization).

7. Demographic data (age, gender, education, specialization, relationship with people with disabilities) as well as consent to the use of data, preceded by the disclosure of the real purpose of the study.

\section{Procedure}

As a part of the larger project, the research was positively evaluated by the Scientific Research Ethic Committee at the Department of Psychology at Jan Kochanowski University in Kielce (KEBN-KP-UJK 1/2020, issued on October 8, 2020). The psychometric assessment of the IAT-VIMD focused on content, external and theoretical validity, and absolute stability. The analysis of content validity was preceded by the selection of five categories of photographs: nondisabled people, people with an intellectual disability, a motor disability, a visual disability as well as people with dwarfism. In developing a tool based on the IAT technique, it is crucial to consider the prototypicality (representativeness) of test items (Maison, 2004). Therefore, the selection of appropriate photographs took into account the degree in which particular kinds of disability are visible as well as the psychosocial activity of the people presented in the photographs, which is considered an important factor in the evaluation of other people. In the initial phase, a series of photographs was collected in a twofold way: first, by searching for $\mathrm{CC} 0$-licensed pictures in the public Internet domain, which do not require the author's consent to use; second, by searching for five types of people and using their photographs, after obtaining appropriate consent from them or their legal guardians. Next, 76 pictures of nondisabled and disabled people were presented to 16 competent experts (students of the 3rd year of psychology who have finished the course in Rehabilitation Psychology). Their task was to analyze each photograph presented to them in an electronic form (JPEG file) in three aspects. First, they had to classify each person into one of five categories: nondisabled (p), physically disabled (r), intellectually disabled (i), with a vision dysfunction (v), or with dwarfism (n). Secondly, the raters needed to assess the degree in which each type of disability was visible, and thirdly, their task was to assess the level of life activity of a person presented in the photographs. The theoretical explanation for life activity as a factor of implicit assessment complies with the Theory of Normative Assumptions (Reykowski, 1990). My previous research indicates that the Individual Productivity (the willingness to undertake life tasks), the Individual Synergy (the ability to manage one's emotions), and, finally, the Collective Synergy (the ability to coexist with others on friendly terms) affect the 
personal attitude toward disabled adult persons (Kurtek, 2018). Therefore, I assumed that life activity may be an important factor in the evaluation (the depreciation vs the appreciation) of disabled people.

The level of inter-rater agreement as regards qualitative assessments was tested with Fleiss' Kappa and the quantitative data were tested with Kendall's W test. The differences in the context, i.e. the overall life activity of the individual, were compared using ANOVA for independent groups, after verification of the sample's distribution normality.

Selected photographs were used in the test-retest study using a computer version of the IAT-VIMD to verify the absolute stability of the test. Participation in the pilot study was voluntary. Students of different departments were invited to participate in the study via a direct contact. Next, a link was sent to them with a specific instruction assuring anonymity. The survey had been conducted online for a period of one month until the minimum double-data size (30 test-retest for a particular type of disability) was gained. Participants completed the experiment individually. All computer tasks were formatted in JPEG and were presented on notebook computers at $1024 \times 768$ pixels. The study of absolute stability sought to exclude situational variables which could modify participants' attention; therefore, the subjects were asked to perform a retest after 20 minutes, in analogous conditions. The results of correlation tests (Pearson's and R-Spearman's) as well as Student's t-test allowed us to conclude about the stability of measurement. The selection of a correlation coefficient was preceded by the testing of normality of the data distribution based on the Kolmogorow-Smirnov and Liliefors tests, which indicated lack of differences between the obtained distributions and the normal distribution $(p>.20)$. Only in the case of the $2 \mathrm{~V}-\mathrm{NC}$ series (the second measurement of response to persons with a visual disability in a noncompatible condition) and the 2I-NC series (the second measurement of response to persons with an intellectual disability in a non-compatible condition), the Liliefors test show lack of normality of the distribution $(p<.05)$, although the Kolmogorow-Smirnov test indicated the normality of a sample $(p>.20)$.

Due to a continuous nature of variables and confirmation of the normality of distribution for most of the data, the $r$-Pearson test was used to assess repeatability of measurements. Simultaneously, due to a small sample size, it was also decided to test the stability of results with the nonparametric $R$-Spearman test. Also, average response times from the first and second tests were compared based on the t-test for dependent data.

Finally, the respondents completed the Conditional Respect for Persons with Disabilities Questionnaire (CRPD-Q) (Kurtek, 2018) to assess the external validity of the IAT-VIMD. The questionnaire, based on the Theory of Normative Assumptions (Reykowski, 1990) examines five categories of respect: Individual 
Productivity, Individual and Collective Synergy (Factor of Acceptance), as well as Individual Receptiveness and Antagonism (Factor of Rejection), and eventually the global indicator of Conditional Respect. The statistical analysis proved the stability and the internal consistency of the tool (Cronbach's $\alpha$ of the items for the identified categories of normative beliefs ranges from .73 to .83). The statistical analysis was conducted using the SPSS and Statistica 13.1 software.

\section{Participants}

The psychometric assessment of the IAT-VIMD included the analysis of its theoretical, content, and external validity as well as absolute stability (as indicator of reliability). To assess content validity, expert judgment was used, while reliability and external validity were assessed based on a pilot study. A voluntary sample was used, as this type of sampling allows to find people that are well socialized and internally motivated to participate in a study (Brzeziński, 2012). This is particularly important in the case of cost-free tests and those requiring repeated testing. We decided that representativeness was not necessary in stability testing. The testing of stability and external accuracy is not about knowing a given piece of reality in a specific population, but about checking the repeatability of an individual measurement with a particular tool. Although the initial sample included 101 respondents, eventually 92 persons (70 women and 22 men aged 19 to 22 years) participated in a test-retest procedure based on IAT-VIMD and 77 respondents (60 female and 17 male) performed additionally the CRPD-Q. The final 92-person research sample was comprised of the students of humanities (45\%), social sciences (27\%), natural sciences $(15 \%)$ and technical studies $(13 \%)$, living in a city $(57 \%)$ or a village $(43 \%)$, of whom $17 \%$ had a direct and permanent contact with a disabled person.

\section{RESULTS}

\section{Estimation of the Content and External Validity of the IAT-VIMD}

The analysis of content validity included the assessment of inter-rater agreement with respect to the specificity of the person presented in the photograph, the degree in which a particular feature is visible and the degree of the person's activity. However, at the very beginning it was decided (apriori) to adopt a minimum agreement criterion as 12 out of 16 experts ( $3 / 4$ of raters). This criterion was met by 
52 photographs (no. 1, 5, 6, 8, 10-12, 14-18, 20, 22, 28, 29, 32, 33, 35, 37, 39-41, $43-50,52-54,57,58,60-73,75,76)$, representing all of the above-mentioned categories of people except for individuals with dwarfism. Photograph no. 32 showed a person with an intellectual disability but was classified mostly as a picture presenting a non-disabled person, and thus was removed from the set. Then, the raters' categorizations of the 51 photographs selected in this way were tested with Fleiss' Kappa to measure the reliability of agreement among raters (for nominal data). The results are presented in Table 1.

\section{Table 1}

Kappa-Fleiss Indicators for Judges' Agreement on the Types of Objects (Nondisabled and Disabled)

\begin{tabular}{lcc}
\hline \multicolumn{1}{c}{ Group } & Fleiss' Kappa & $Z$ \\
\hline Non-disabled & $0.90[0.87-0.93]$ & $69.71^{*}$ \\
Visually disabled & $0.91[0.88-0.93]$ & $70.17^{*}$ \\
With a motor disability & $0.87[0.84-0.89]$ & $67.19^{*}$ \\
Intellectually disabled & $0.83[0.80-0.85]$ & $64.08^{*}$ \\
\hline
\end{tabular}

Note. Values in square brackets indicate the $95 \%$ confidence intervals for each Fleiss' Kappa score. $* p<.001$.

The obtained Fleiss' Kappa results indicate statistically significant consistency of the experts' categorizations of the photographs of non-disabled as well as visually, intellectually and physically disabled people, which confirms the content validity of the selected photographs.

Next, the 51 selected photographs were tested for the degree of visibility of a particular disability. The experts rated each photograph on a scale from 1-5, where 1 meant very low, 3 was average, and 5 denoted very high visibility of a given disability. The choices of 55 raters which were different from the dominant ratings for particular photographs were eliminated from the pool. The degree of visibility of a particular disability was measured with two indicators: an average score for each photograph obtained from experts' ratings and the rating consistency result obtained with Kendall's $W$ test. The experts' evaluation ratings are presented in Table 2. 


\section{Table 2}

Judges' Ratings of Visibility Level of Object's Specificity (Scores Range: 1-5)

\begin{tabular}{|c|c|c|c|c|c|c|c|c|c|c|c|c|c|c|c|c|c|c|}
\hline $\begin{array}{c}\text { No \& } \\
\text { category } \\
\text { of object }\end{array}$ & 1 & 2 & 3 & 4 & 5 & 6 & 7 & 8 & 9 & 10 & 11 & 12 & 13 & 14 & 15 & 16 & $M$ & $S D$ \\
\hline $1 \mathrm{~N}-\mathrm{D}$ & 1 & 4 & 1 & 4 & 4 & 4 & 2 & 4 & 5 & 4 & 1 & 4 & 4 & 4 & 1 & 1 & 3.00 & 1.41 \\
\hline $5 \mathrm{~N}-\mathrm{D}$ & 1 & 3 & 1 & 5 & 5 & 5 & 5 & 4 & 5 & 5 & 1 & 5 & 5 & 4 & 5 & 4 & 3.94 & 1.47 \\
\hline $6 \mathrm{M}$ & - & 5 & 1 & 5 & 5 & 5 & 5 & 5 & 4 & 4 & 4 & 5 & 5 & 3 & 5 & 5 & 4.40 & 1.05 \\
\hline $8 \mathrm{M}$ & - & 5 & - & 5 & 5 & 5 & 5 & 5 & - & 4 & 4 & 5 & 2 & 3 & 5 & 5 & 4.46 & 0.90 \\
\hline $10 \mathrm{M}$ & 5 & 5 & 5 & 5 & 5 & 5 & 5 & 5 & 5 & 5 & 4 & 5 & 5 & 5 & 5 & 5 & 4.94 & 0.23 \\
\hline $11 \mathrm{~V}$ & 5 & 5 & 5 & 4 & 5 & 5 & 5 & 5 & 5 & 3 & 3 & 5 & 5 & 5 & 5 & 5 & 4.69 & 0.66 \\
\hline $12 \mathrm{~N}-\mathrm{D}$ & 4 & 3 & 1 & 3 & 5 & 3 & 4 & 3 & 5 & 4 & 3 & 4 & 4 & - & 3 & 4 & 3.53 & 0.93 \\
\hline $14 \mathrm{M}$ & 5 & 5 & 5 & 5 & 5 & 5 & 5 & 5 & 5 & 4 & 4 & 5 & 5 & 3 & 5 & 5 & 4.75 & 0.54 \\
\hline $15 \mathrm{M}$ & 5 & 4 & 1 & 5 & 5 & 5 & 5 & 5 & 5 & 4 & 4 & 5 & 5 & 3 & 5 & 5 & 4.44 & 1.03 \\
\hline $16 \mathrm{~V}$ & 5 & 5 & 5 & 5 & 5 & 5 & 5 & 5 & 5 & 3 & 2 & 5 & 4 & 4 & 5 & 5 & 4.56 & 0.84 \\
\hline $17 \mathrm{M}$ & 5 & 4 & - & 3 & - & 5 & 4 & 5 & 5 & 3 & 4 & 5 & 4 & 4 & 5 & 5 & 4.36 & 0.69 \\
\hline $18 \mathrm{M}$ & 5 & 5 & 5 & 5 & - & 5 & 5 & 5 & 5 & 4 & 4 & 5 & 5 & 5 & 5 & 5 & 4.87 & 0.33 \\
\hline 20I & - & 4 & 4 & 5 & 4 & - & 4 & 5 & 5 & 4 & 3 & 4 & - & 4 & 5 & - & 4.25 & 0.57 \\
\hline 22I & - & 5 & - & 5 & 4 & 3 & 5 & 5 & 5 & 4 & 4 & 5 & 4 & 4 & 5 & 5 & 4.50 & 0.61 \\
\hline $28 \mathrm{I}$ & 4 & 1 & - & 5 & 3 & 3 & 1 & 4 & 4 & 4 & 3 & 2 & 4 & 5 & 5 & 4 & 3.47 & 1.22 \\
\hline 29I & 3 & 4 & 5 & - & - & 3 & - & 3 & 5 & 2 & 3 & 4 & 3 & 4 & 5 & 3 & 3.62 & 0.89 \\
\hline 33I & 4 & 5 & 5 & 5 & 5 & - & 5 & 5 & 5 & - & 4 & 4 & - & - & 5 & 5 & 4.75 & 0.42 \\
\hline $35 \mathrm{M}$ & 1 & - & 1 & - & 5 & 5 & 5 & - & 5 & 4 & 4 & 5 & 4 & 3 & 5 & 5 & 4.00 & 1.36 \\
\hline $37 \mathrm{I}$ & - & 5 & - & 5 & 5 & 5 & 1 & 5 & 5 & 3 & 3 & 4 & 4 & 4 & 5 & 3 & 4.07 & 1.12 \\
\hline $39 \mathrm{~N}-\mathrm{D}$ & 5 & 4 & 5 & 5 & 5 & 5 & 5 & 4 & 5 & 4 & 4 & 4 & 5 & 3 & - & 5 & 4.53 & 0.60 \\
\hline $40 \mathrm{I}$ & 5 & 5 & 5 & 5 & 5 & 5 & 1 & 5 & 5 & 3 & 3 & 5 & 2 & 5 & 5 & 5 & 4.31 & 1.22 \\
\hline $41 \mathrm{I}$ & 5 & 5 & 5 & 5 & 3 & 5 & 5 & 5 & 5 & 4 & - & - & 4 & 3 & 2 & 5 & 4.36 & 0.94 \\
\hline $43 \mathrm{~N}-\mathrm{D}$ & 5 & 4 & 1 & 2 & 3 & 1 & 1 & 5 & 4 & 4 & 4 & 1 & 4 & 5 & - & 3 & 3.13 & 1.45 \\
\hline $44 \mathrm{M}$ & 5 & 4 & 5 & 5 & 5 & 5 & - & 5 & 5 & 3 & 4 & 5 & 4 & - & - & 5 & 4.62 & 0.60 \\
\hline
\end{tabular}




\begin{tabular}{|c|c|c|c|c|c|c|c|c|c|c|c|c|c|c|c|c|c|c|}
\hline $45 \mathrm{M}$ & 5 & 5 & 5 & 5 & 5 & 5 & 5 & 5 & 5 & 4 & 4 & 5 & 5 & 4 & 5 & 5 & 4.81 & 0.38 \\
\hline $46 \mathrm{~N}-\mathrm{D}$ & 5 & 5 & 1 & 5 & 5 & 5 & 5 & 5 & 5 & 5 & 4 & 5 & 5 & 4 & 5 & 5 & 4.63 & 0.96 \\
\hline 47I & 5 & 5 & - & 4 & 4 & 4 & 5 & 5 & 5 & - & 3 & 5 & 5 & 4 & - & 5 & 4.54 & 0.61 \\
\hline $48 \mathrm{~N}-\mathrm{D}$ & 5 & 4 & - & 4 & 4 & 5 & 5 & 4 & 5 & 4 & 4 & 2 & 5 & 4 & 3 & 5 & 4.20 & 0.81 \\
\hline $49 \mathrm{M}$ & 5 & 5 & 5 & 5 & 5 & 5 & 5 & 4 & 5 & 3 & 3 & 3 & 4 & 3 & 3 & 5 & 4.25 & 0.87 \\
\hline $50 \mathrm{~N}-\mathrm{D}$ & 5 & 5 & - & 2 & 3 & 5 & 5 & 5 & 3 & 4 & 4 & 3 & 3 & 3 & 5 & 5 & 4.00 & 1.00 \\
\hline $52 \mathrm{~N}-\mathrm{D}$ & 5 & 5 & 5 & 5 & 4 & 5 & 5 & 5 & 5 & 4 & 4 & 3 & 4 & 5 & 5 & 5 & 4.63 & 0.58 \\
\hline $53 \mathrm{~N}-\mathrm{D}$ & 5 & 5 & 5 & 5 & 3 & 5 & 5 & 5 & 5 & 4 & 4 & 4 & 5 & 4 & 3 & 5 & 4.50 & 0.69 \\
\hline $54 \mathrm{~N}-\mathrm{D}$ & 5 & 5 & 5 & 5 & 4 & 3 & 5 & 5 & 4 & 4 & 4 & 3 & 4 & 5 & 3 & 5 & 4.31 & 0.75 \\
\hline 57I & 5 & 5 & 5 & 5 & 5 & 5 & 5 & 5 & 5 & 4 & 4 & 4 & 5 & 4 & 5 & 5 & 4.75 & 0.42 \\
\hline $58 \mathrm{M}$ & 5 & 5 & 5 & 5 & 5 & 5 & 5 & 5 & 5 & 3 & 3 & 4 & 2 & 4 & 4 & 5 & 4.38 & 0.90 \\
\hline $60 \mathrm{~N}-\mathrm{D}$ & 4 & 3 & 5 & 4 & 4 & 4 & 3 & 5 & 3 & 4 & 3 & 3 & 5 & 5 & 4 & 3 & 3.88 & 0.76 \\
\hline $61 \mathrm{~V}$ & 5 & 5 & 4 & 5 & - & 5 & 5 & 5 & 5 & 5 & 4 & 4 & 5 & 5 & 5 & 4 & 4.73 & 0.43 \\
\hline $62 \mathrm{~N}-\mathrm{D}$ & 5 & 4 & 5 & 5 & 4 & 3 & 4 & 2 & 2 & 3 & 4 & 4 & 5 & 3 & 4 & 2 & 3.69 & 1.01 \\
\hline $63 \mathrm{~V}$ & 5 & 5 & 5 & 4 & 4 & 4 & 4 & 4 & 5 & 5 & 5 & 4 & 5 & 5 & 5 & 4 & 4.56 & 0.48 \\
\hline $64 \mathrm{~N}-\mathrm{D}$ & 5 & 5 & 5 & 5 & 5 & 4 & 5 & 5 & 3 & 3 & 5 & 5 & 5 & 5 & 3 & 5 & 4.56 & 0.76 \\
\hline $65 \mathrm{~V}$ & 5 & 4 & 3 & 4 & 3 & 4 & 3 & 2 & 5 & 5 & 3 & 4 & 2 & 4 & 5 & 4 & 3.75 & 0.94 \\
\hline $66 \mathrm{~V}$ & 5 & 5 & 5 & 5 & 4 & 4 & 4 & 4 & 4 & 5 & 4 & 4 & 5 & 5 & 5 & 4 & 4.50 & 0.49 \\
\hline $67 \mathrm{~N}-\mathrm{D}$ & 5 & 4 & 5 & 5 & - & 4 & 3 & 1 & 3 & 3 & 3 & 3 & - & 5 & 2 & 4 & 3.57 & 1.14 \\
\hline $68 \mathrm{~N}-\mathrm{D}$ & 5 & 5 & 5 & 5 & 5 & 4 & 5 & 5 & 4 & 4 & 5 & 4 & 5 & 5 & 5 & 5 & 4.75 & 0.42 \\
\hline $69 \mathrm{~V}$ & 5 & 5 & 5 & 4 & 5 & 5 & - & - & 4 & 5 & 4 & 5 & 5 & 5 & 4 & 4 & 4.64 & 0.46 \\
\hline $70 \mathrm{~V}$ & 5 & 5 & 5 & 5 & 4 & 4 & 4 & 4 & 5 & 5 & 4 & 5 & 5 & 5 & 5 & 4 & 4.63 & 0.47 \\
\hline $71 \mathrm{~V}$ & 5 & 5 & 5 & 3 & 4 & 4 & 3 & 4 & 5 & 5 & 4 & 5 & 5 & 5 & 5 & 3 & 4.38 & 0.76 \\
\hline $72 \mathrm{~N}-\mathrm{D}$ & 4 & 4 & 5 & 5 & 3 & 4 & 5 & 3 & 3 & 3 & 4 & 4 & 3 & 5 & 3 & 5 & 3.94 & 0.80 \\
\hline $73 \mathrm{M}$ & 5 & 5 & 4 & 5 & 5 & 5 & 5 & 5 & 5 & 5 & 4 & 5 & 5 & 5 & 5 & 4 & 4.81 & 0.38 \\
\hline $75 \mathrm{M}$ & 5 & 5 & 4 & 5 & 5 & 5 & 5 & 5 & 5 & 5 & 5 & 5 & 5 & 5 & 4 & 5 & 4.88 & 0.32 \\
\hline 76I & 5 & 4 & 4 & - & - & 3 & 2 & 4 & 5 & 4 & 5 & 4 & - & 5 & 2 & - & 3.92 & 1.00 \\
\hline
\end{tabular}

Note. $\mathrm{M}=$ with a motor disability, $\mathrm{I}=$ intellectually disabled, $\mathrm{V}=$ visually disabled, $\mathrm{N}-\mathrm{D}=$ nondisabled. 
Based on the analysis of arithmetic means for the level of visibility of particular disabilities, photographs with a value below 3.60 (items 1, 12, 28, 43, 67) were rejected, i.e., only those photographs that best represent a specific type of disability were accepted for further processing (missing data at this stage were replaced by average scores). A set of 46 pictures selected in this way was analyzed using Kendall's $W$ statistic. The obtained $W$ value was low but statistically significant at the level of $p<.001\left(\chi^{2}=197.856, d f=45, W=.247, N=16\right.$; the estimation was based on the approximation of a $W$ distribution to a chi-square distribution). The low $W$ value points to a discrepancy between the experts' ratings. However, considering that the final pool includes photographs that were mainly assessed as good (rated 4 ) or very good (rated 5), the statistical discrepancy between such high ratings does not seem to diminish the content value of the selected set of photographs. Therefore, the analysis of the results seems to confirm the content validity of the tool in terms of the visibility of particular kinds of disability.

Taking into account the importance of context (background) in the evaluation of objects, the level of psychosocial activity of individuals presented in each photograph was also assessed. For this purpose, an analogous procedure was carried out using the same raters. Their task was to assess the psychosocial activity of 46 people on a scale from 1 to $5(1=$ very low, $2=$ low, $3=$ average, $4=$ high, $5=$ very high $)$. The results obtained are summarized in Table 3.

Similarly, the obtained $W$-Kendall value $\left(\chi^{2}=227.15, d f=45, W=.323\right.$; $N=16$; the evaluation was based on the approximation of a $W$ distribution to a chisquare distribution) turned to be low but statistically significant at $p<.001$, which indicates a tendency in the raters' agreement in the assessment of the psychosocial participation of individuals presented in the photographs.

Then, similarity was measured between particular groups of photographs in terms of psychosocial life activity of the people shown in the pictures. The comparison of means and standard deviations for psychosocial activity in particular categories of persons (nondisabled -3.76 and 0.52 vs disabled people: physically-3.69 and 0.67 , intellectually -3.84 and 0.37 , or visually -3.54 and 0.88 ) was performed using ANOVA. Prior to conducting the analysis, the assumption about the normal distribution for psychosocial activity was tested with the Shapiro-Wilk and Liliefors statistics $(p>.05)$ in relation to the photographs presenting four groups of people, while the assumption about the equality of variance was verified with the Levene test $(p=.042)$. This allowed us to use the parametric ANOVA test for independent groups. The results $(F(3,42)=0.370 ; p>.775)$ indicate that there were no statistical differences between the selected groups of photographs; in other words, the photographs are similar in terms of the psychosocial activity of the people shown in the pictures. Therefore, we can assume that this variable has no effect on implicit attitudes towards the examined objects. 


\section{Table 3}

Judges' Ratings of General Life Activity of Nondisabled and Disabled Persons Presented in Photographs (Scores Range: 1-5)

\begin{tabular}{|c|c|c|c|c|c|c|c|c|c|c|c|c|c|c|c|c|c|c|}
\hline $\begin{array}{c}\text { No \& } \\
\text { category } \\
\text { of object }\end{array}$ & 1 & 2 & 3 & 4 & 5 & 6 & 7 & 8 & 9 & 10 & 11 & 12 & 13 & 14 & 15 & 16 & $M$ & $S D$ \\
\hline $6 \mathrm{M}$ & 1 & 5 & 5 & 5 & 5 & 5 & 5 & 4 & 5 & 3 & 4 & 5 & 5 & 5 & 5 & 5 & 4.5 & 1.06 \\
\hline $8 \mathrm{M}$ & 5 & 5 & 5 & 5 & 5 & 5 & 5 & 5 & 5 & 5 & 4 & 5 & 5 & 4 & 5 & 5 & 4.88 & 0.33 \\
\hline $10 \mathrm{M}$ & 5 & 5 & 5 & 5 & 5 & 5 & 5 & 5 & 5 & 5 & 4 & 5 & 5 & 4 & 5 & 5 & 4.88 & 0.33 \\
\hline $14 \mathrm{M}$ & 4 & 3 & 4 & 3 & 2 & 5 & 4 & 4 & 2 & 3 & 2 & 4 & 4 & 4 & 2 & 4 & 3.38 & 0.93 \\
\hline $15 \mathrm{M}$ & 1 & 4 & 3 & 5 & 4 & 3 & 5 & 3 & 2 & 3 & 2 & 4 & 4 & 2 & 3 & 1 & 3.06 & 1.20 \\
\hline $17 \mathrm{M}$ & 5 & 5 & 4 & 3 & 4 & 5 & 5 & 3 & 2 & 3 & 2 & 3 & 4 & 3 & 3 & 1 & 3.44 & 1.17 \\
\hline $18 \mathrm{M}$ & 5 & 2 & 5 & 4 & 5 & 5 & 5 & 5 & 2 & 4 & 2 & 4 & 5 & 4 & 4 & 5 & 4.13 & 1.11 \\
\hline $35 \mathrm{M}$ & 1 & 5 & 1 & 1 & 3 & 3 & 5 & 3 & 3 & 3 & 2 & 2 & 3 & 5 & 2 & 1 & 2.69 & 1.36 \\
\hline $44 \mathrm{M}$ & 4 & 4 & 2 & 4 & 4 & 1 & 1 & 4 & 4 & 2 & 3 & 4 & 2 & 5 & 3 & 3 & 3.13 & 1.17 \\
\hline $45 \mathrm{M}$ & 1 & 5 & 5 & 3 & 4 & 2 & 5 & 5 & 2 & 4 & 2 & 1 & 4 & 2 & 5 & 1 & 3.19 & 1.55 \\
\hline $49 \mathrm{M}$ & 5 & 4 & 1 & 5 & 4 & 1 & 5 & 4 & 5 & 3 & 3 & 3 & 4 & 4 & 3 & 4 & 3.63 & 1.22 \\
\hline $58 \mathrm{M}$ & 4 & 5 & 3 & 5 & 4 & 2 & 5 & 5 & 3 & 3 & 3 & 3 & 4 & 4 & 3 & 4 & 3.75 & 0.90 \\
\hline $73 \mathrm{M}$ & 5 & 3 & 3 & 2 & 4 & 2 & 3 & 2 & 4 & 4 & 3 & 4 & 5 & 3 & 4 & 3 & 3.38 & 0.93 \\
\hline $75 \mathrm{M}$ & 4 & 3 & 3 & 2 & 4 & 3 & 4 & 4 & 4 & 4 & 4 & 3 & 5 & 4 & 4 & 3 & 3.63 & 0.70 \\
\hline 20I & 5 & 5 & 4 & 4 & 3 & 4 & 5 & 4 & 2 & 2 & 2 & 5 & 4 & 4 & 4 & 4 & 3.81 & 1.01 \\
\hline 22I & 1 & 4 & 4 & 5 & 3 & 5 & 3 & 4 & 3 & 3 & 3 & 5 & 4 & 3 & 3 & 1 & 3.38 & 1.17 \\
\hline 29I & 5 & 1 & 5 & 5 & 4 & 5 & 4 & 5 & 3 & 3 & 3 & 3 & 5 & 5 & 4 & 5 & 4.06 & 1.14 \\
\hline $33 \mathrm{I}$ & 2 & 4 & 2 & 5 & 4 & 5 & 5 & 4 & 3 & 4 & 3 & 3 & 4 & 3 & 4 & 2 & 3.56 & 1.00 \\
\hline $37 \mathrm{I}$ & 5 & 3 & 2 & 4 & 3 & 4 & 5 & 4 & 4 & 3 & 2 & 1 & 3 & 5 & 2 & 1 & 3.19 & 1.29 \\
\hline $40 I$ & 5 & 4 & 3 & 5 & 4 & 5 & 5 & 4 & 5 & 3 & 4 & 3 & 3 & 4 & 5 & 5 & 4.19 & 0.81 \\
\hline $41 \mathrm{I}$ & 5 & 5 & 4 & 5 & 5 & 5 & 5 & 5 & 3 & 3 & 3 & 2 & 4 & 4 & 5 & 5 & 4.25 & 0.97 \\
\hline $47 \mathrm{I}$ & 5 & 4 & 5 & 4 & 4 & 3 & 5 & 5 & 5 & 4 & 3 & 3 & 5 & 3 & 5 & 5 & 4.25 & 0.83 \\
\hline 57I & 5 & 5 & 5 & 2 & 4 & 5 & 5 & 4 & 3 & 3 & 3 & 3 & 4 & 4 & 3 & 5 & 3.94 & 0.97 \\
\hline
\end{tabular}




\begin{tabular}{|c|c|c|c|c|c|c|c|c|c|c|c|c|c|c|c|c|c|c|}
\hline 76I & 5 & 4 & 3 & 3 & 3 & 3 & 3 & 4 & 5 & 4 & 4 & 4 & 4 & 4 & 3 & 4 & 3.75 & 0.66 \\
\hline $11 \mathrm{~V}$ & 5 & 5 & 1 & 1 & 3 & 4 & 5 & 3 & 3 & 2 & 2 & 3 & 2 & 3 & 2 & 3 & 2.94 & 1.25 \\
\hline $16 \mathrm{~V}$ & 1 & 4 & 1 & 3 & 5 & 3 & 3 & 2 & 1 & 2 & 1 & 1 & 4 & 3 & 3 & 1 & 2.38 & 1.27 \\
\hline $61 \mathrm{~V}$ & 2 & 2 & 5 & 3 & 2 & 3 & 3 & 2 & 2 & 2 & 2 & 2 & 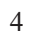 & 4 & 4 & 4 & 2.88 & 0.99 \\
\hline $63 \mathrm{~V}$ & 1 & 4 & 5 & 2 & 2 & 3 & 3 & 2 & 3 & 3 & 2 & 2 & 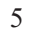 & 3 & 4 & 2 & 2.88 & 1.11 \\
\hline $65 \mathrm{~V}$ & 5 & 5 & 5 & 5 & 5 & 4 & 5 & 4 & 5 & 5 & 5 & 5 & 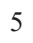 & 5 & 5 & 5 & 4.88 & 0.33 \\
\hline $66 \mathrm{~V}$ & 5 & 5 & 4 & 3 & 3 & 4 & 3 & 3 & 3 & 3 & 5 & 5 & 3 & 4 & 4 & 4 & 3.81 & 0.81 \\
\hline $69 \mathrm{~V}$ & 4 & 5 & 5 & 5 & 5 & 4 & 5 & 5 & 5 & 5 & 5 & 3 & 5 & 5 & 5 & 5 & 4.75 & 0.56 \\
\hline $70 \mathrm{~V}$ & 5 & 4 & 3 & 4 & 3 & 4 & 5 & 3 & 5 & 5 & 4 & 3 & ( & 3 & 5 & 4 & 4.06 & 0.83 \\
\hline $71 \mathrm{~V}$ & 4 & 4 & 3 & 3 & 4 & 3 & 3 & 3 & 3 & 3 & 3 & 3 & J & 3 & 3 & 3 & 3.31 & 0.58 \\
\hline $5 \mathrm{P}$ & 1 & 5 & 5 & 4 & 5 & 5 & 4 & 4 & 4 & 4 & 3 & 4 & 4 & 4 & 5 & 1 & 3.88 & 1.22 \\
\hline $39 \mathrm{~N}-\mathrm{D}$ & - & 5 & 4 & 3 & 5 & 5 & 1 & 4 & 2 & 3 & 3 & 4 & 5 & 5 & 3 & 4 & 3.73 & 1.18 \\
\hline $46 \mathrm{~N}-\mathrm{D}$ & 5 & 5 & 5 & 5 & 5 & 5 & 5 & 5 & 5 & 4 & 3 & 5 & 5 & 4 & 5 & 5 & 4.75 & 0.56 \\
\hline $48 \mathrm{~N}-\mathrm{D}$ & 5 & 5 & 5 & 5 & 5 & 5 & 5 & 4 & 5 & 4 & 3 & 5 & 5 & 3 & 5 & 5 & 4.63 & 0.70 \\
\hline $50 \mathrm{~N}-\mathrm{D}$ & 5 & 4 & 1 & 5 & 5 & 2 & 5 & 4 & 3 & 3 & 3 & 3 & 3 & 3 & 3 & 5 & 3.56 & 1.17 \\
\hline $52 \mathrm{~N}-\mathrm{D}$ & 5 & 4 & 3 & 3 & 4 & 5 & 5 & 4 & 3 & 4 & 3 & 4 & 3 & 4 & 5 & 3 & 3.88 & 0.78 \\
\hline $53 \mathrm{~N}-\mathrm{D}$ & 2 & 5 & 3 & 5 & 2 & 5 & 3 & 3 & 4 & 3 & 2 & 3 & 3 & 5 & 3 & 2 & 3.31 & 1.10 \\
\hline $54 \mathrm{~N}-\mathrm{D}$ & 5 & 3 & 3 & 5 & 4 & 5 & 5 & 5 & 4 & 4 & 3 & 2 & 5 & 4 & 4 & 5 & 4.13 & 0.93 \\
\hline $60 \mathrm{~N}-\mathrm{D}$ & 1 & 2 & 1 & 2 & 4 & 3 & 5 & 3 & 5 & 3 & 2 & 3 & $T$ & 5 & 3 & 1 & 2.94 & 1.34 \\
\hline $62 \mathrm{~N}-\mathrm{D}$ & 5 & 5 & 2 & 4 & 3 & 3 & 4 & 2 & 4 & 4 & 3 & 3 & 5 & 4 & 3 & 4 & 3.63 & 0.93 \\
\hline $64 \mathrm{~N}-\mathrm{D}$ & 4 & 5 & 2 & 4 & 4 & 3 & 4 & 3 & 4 & 4 & 3 & 3 & 5 & 4 & 4 & 3 & 3.69 & 0.77 \\
\hline $68 \mathrm{~N}-\mathrm{D}$ & 3 & 3 & 5 & 4 & 2 & 3 & 3 & 2 & 2 & 2 & 4 & 2 & 5 & 3 & 4 & 3 & 3.13 & 0.99 \\
\hline $72 \mathrm{~N}-\mathrm{D}$ & 5 & 5 & 3 & 2 & 4 & 2 & 3 & 4 & 4 & 4 & 3 & 4 & 2 & 4 & 4 & 3 & 3.5 & 0.94 \\
\hline
\end{tabular}

Note. $\mathrm{M}=$ with a motor disability, $\mathrm{I}=$ intellectually disabled, $\mathrm{V}=$ visually disabled, $\mathrm{N}-\mathrm{D}=$ nondisabled.

Eventually, the following 46 photographs for particular categories of people were selected for the final version of the test:

- non-disabled $(5,39,46,48,50,52-54,60,62,64,68,72)$-13 items, 
- intellectually disabled $(20,22,29,33,37,40,41,47,57,76)$ - 10 items,

- physically disabled $(6,8,10,14,15,1718,35,44,45,49,58,73,75)$ 14 items,

- visually disabled $(11,16,61,63,65,66,69,70,71)-9$ items.

In the next step, we wanted to assess the external validity of the test. As the Polish market lacks diagnostic tools to measure implicit attitudes towards disabled people, the choice of an appropriate criterion was a challenge at that point. Therefore, although calculating the external validity based on comparisons of results for implicit and explicit attitudes (which may be independent) is questionable, we decided to use this type of measure. The external accuracy of the IAT-VIMD was tested by comparing the difference in reaction times in compatible versus incompatible conditions with the intensity of General Conditional Respect, the Conditional Acceptance and the Conditional Rejection indicators based on the self-report questionnaire (CRPD-Q). We assumed that the lower the difference in reaction times, the lower the criticism (Factor of Rejection) and the higher the appreciation (Factor of Acceptance) as well as higher unconditional respect towards disabled people. However, a non-parametric correlation analysis (Spearman), conducted due to lack of normality distribution of individual aspects of Conditional Respect, showed a positive correlation between the differences in reaction times in compatible and noncompatible conditions and the intensity of Conditional Rejection $(.25 ; p<.05)$. Other correlations with Conditional Acceptance $(.004 ; p>.05)$ and General Conditional Respect were statistically insignificant. It means that the IAT-VIMD index is more sensitive to negative (criticism intensity) than positive social assessment.

In addition, comparisons (based on T-test for dependent samples) as regards to visually, motor and intellectually disabled objects in compatible vs noncompatible conditions were carried out.

\section{Table 4}

Comparisons of Categorization Times of Persons With Visual, Motor and Intellectual Disabilities in Compatible (C) vs Noncompatible (NC) Conditions

\begin{tabular}{lcccccc}
\hline \multicolumn{1}{c}{ Object type } & $M c$ & $S . D c$ & $M n c$ & $S . D n c$ & $d f$ & $t$ \\
\hline Visually disabled & 1.05 & 0.23 & 1.22 & 0.22 & 59 & $-5.67^{*}$ \\
With a motor disability & 0.97 & 0.21 & 1.19 & 0.23 & 59 & $-9.96^{*}$ \\
Intellectually disabled & 0.98 & 0.19 & 1.16 & 0.23 & 61 & $-8.25^{*}$ \\
\hline
\end{tabular}

$* p<.001$. 
The results point to the IAT effects $(p<.001)$, i.e. responding is longer in noncompatible conditions (Flowers plus the disabled and Insects plus the non-disabled) concerning all particular groups, which confirms the theoretical assumptions of the tool. Despite the limited sample size, I made an additional analysis comparing the time of reaction in compatible, noncompatible and the arithmetic difference between these times (as dependent variables) considering sex, direct contact with the disabled and place of residence (as independent variables) based on the Mann-Whitney $\mathrm{U}$ test. The only statistical difference was observed as refer to the contact with a disabled person as the independent variable. The respondents with direct contacts need more time for categorization in assumed compatible conditions $(U=100.0$; $Z=2.34 ; p=.02)$. Moreover, the difference between the reaction time in compatible and noncompatible conditions is bigger in the respondents without the direct contact with the disabled $(U=125, z=1.79 ; p=.07)$. Therefore, the cognitive division on the "disabled and insects" contra "nondisabled and flowers" is more obvious for respondents without the direct contact with the disabled comparing to the other group.

\section{Estimation of Reliability of the IAT-VIMD}

To analyze the reliability of the IAT-VIMD, the absolute stability of the tool was measured. Reaction times in the test and the retest in the assumed compatible (Task 4) and next in noncompatible (Task 6) conditions were compared. Prior to conducting the main analysis the reaction times were corrected. Namely, in the case of erroneous responses, the maximum time obtained by a rater in a given condition was assigned, while in the case of too fast or too slow responses (i.e. below $300 \mathrm{~ms}$ or above $3000 \mathrm{~ms}$, respectively), the mean value of the time obtained by a rater in a particular condition was assigned, considering it as the effect of deconcentration (Maison, 2004; Foroni \& Bel-Bahar, 2010). The minimum point of time reaction refers to the evoke potential of P-300 (Szelenberger, 2000).

Then, the comparisons of test and retest reaction times were made to assess the stability of the IAT-VIMD. The obtained data are presented in Table 5.

The data from Table 5 indicate high and significant levels of correlation between the first measurement and the second measurement for all object categories, tested with both a parametric and a non-parametric test $(p<.05)$. These correlations show significant repeatability of categorization times in both compatible and non-compatible conditions. Simultaneously, a significant reduction in reaction times was observed $(p<.01)$ for all categories of objects (i.e. people with visual, motor and intellectual disabilities), based on the $t$ test results. Despite the observed effect of practice, the data prove a good ordering of the examined people according to their 
response times in the second measurement compared to the ordering based on their reaction times in the first measurement. Single shifts in the ordering of the data do not go beyond the variation indicated by the standard deviation for a given sample. This means that performing tasks depends on the specific properties of the test objects, which confirms the stability of the tool.

\section{Table 5}

Comparisons of Categorization Times of Persons With Visual (V), Motor (M), and Intellectual (I) Disabilities in Compatible (C) and Noncompatible (NC) Conditions in Test (1) and Retest (2) Procedure

\begin{tabular}{lccccccc}
\hline $\begin{array}{c}\text { Type of group- } \\
\text { Conditions }\end{array}$ & $M$ & Min & Max & $S D$ & Pearson's $r$ & Spearman's rho & $t(30)$ \\
\hline 1.V-C & 1.125 & 0.757 & 1.691 & 0.216 & $.69^{*}$ & $.73^{*}$ & $4.52^{* *}$ \\
2.V-C & 0.979 & 0.698 & 1.583 & 0.233 & & & \\
1.V-NC & 1.268 & 0.999 & 1.749 & 0.192 & $.68^{*}$ & $.61^{*}$ & $3.18^{* *}$ \\
2.V-NC & 1.166 & 0.833 & 1.632 & 0.238 & & & \\
1.M-C & 1.022 & 0.668 & 1.820 & 0.241 & $.71^{*}$ & $.80^{*}$ & $3.51^{* *}$ \\
2.M-C & 0.914 & 0.652 & 1.328 & 0.150 & & & \\
1.M-NC & 1.238 & 0.837 & 1.672 & 0.194 & $.72^{*}$ & $.53^{*}$ & $3.04^{* *}$ \\
2.M-NC & 1.141 & 0.797 & 1.762 & 0.248 & & & \\
1.I-C & 1.013 & 0.729 & 1.532 & 0.194 & $.68^{*}$ & $.64^{*}$ & $2.32^{*}$ \\
2.I-C & 0.947 & 0.630 & 1.384 & 0.190 & & & \\
1.I-NC & 1.214 & 0.843 & 1.637 & 0.245 & $.68^{*}$ & $.68^{*}$ & $3.24^{* *}$ \\
2.I-NC & 1.101 & 0.774 & 1.481 & 0.195 & & & \\
\hline
\end{tabular}

Note. $1,2=$ the testing order of the same respondents. $* p<.05, * * p<.001$.

\section{DISCUSSION}

The IAT-VIMD test is an image-based online tool that aims to explore implicit attitudes towards people with visual, intellectual, and motor disabilities. However, the presented analysis indicates that IAT-VIMD meets not all criteria of psychometric goodness. Although it was shown the test consists of good items (content validity), additional research is planned to control different aspects of external stimulus (such 
as character of presented objects and their background) that may affect the respondent's response. We observed that the test seems to explore especially the intensity of criticism towards disabled people. Although implicit and explicit attitudes are formed based on the mechanisms of repression or splitting, the interaction between them is possible in replacement and rationalization processes (Whitfiled \& Jordan, 2009; Wilson et al., 2000). As the approval tendency may be a result of social pressure, the rejection tendency may be affected by individual normative assumptions. It may explain the discrepancy (lack of correlation between explicit Acceptance and IAT-index) and congruence (correlation between explicit Rejection and IAT-index) between explicit and implicit attitudes. The courage to reveal an attitude of Conditional Rejection towards disabled people may indicate a reduced need for social acceptance and greater susceptibility to adjusting one's behavior to one's genuine intrapsychic tendencies. However, pointing to the need to explore implicit attitudes towards various groups of disabled people, the research on the assessment of the external validity of the tool should be continued. In particular, the observation of spontaneous behavior in respondents towards people with disabilities could also prove the test's validity. However, the observation method needs multiple and different contexts to exclude situational variance and explore individual tendencies.

It was shown that the tool seems to meet the criteria of theoretical validity, as it complies with the research model developed to study implicit attitudes, and the IAT-index was observed in all studied groups (Greenwald et al., 1998). Thus, the assumption about compatible and non-compatible conditions for categorizing objects proved valid in the analyzed group of respondents (especially for respondents without the direct contact with the disabled). The interpretation of differences in reaction times as manifestations of the favoring of vs. discrimination against specific objects meets the criterion of the theoretical validity of the described tool, as it points to a construct that is a certain postulated property of people, which is assumed to be revealed by the test (Brzeziński, 2012).

The stability of the test was also proved based on test-retest procedure, though, results may be affected by fluctuations in respondents' attention. Therefore, comfortable, stable, and repeatable performance conditions need to be ensured. Moreover, as it is likely that respondents gain practice in performing categorization tasks, it is advisable to maintain an appropriate time interval between two measurements in case of repeated tests.

Since the exploration of implicit associations with disabled persons may be crucial for explaining affective and behavioral aspects of social attitudes, especially in natural circumstances, the presented test is worthy of consideration in integration policy (Sękowski, 2001; Sękowski \& Witkowska, 2002). It may be a useful tool to study the social integration process, evaluate social interventions. The tool may be 
used in the process of selection and recruitment of social workers and special education teachers, as well as in the assessment of occupational burnout among these groups of professionals. For now, due to premature nature of the test, it should not be yet used for intergroup comparisons regarding implicit attitudes towards particular types of disability. However, the implementation of the signaled research tasks will contribute to the development of the test and make it useful.

\section{REFERENCES}

Anthony, W. A. (1977). Societal rehabilitation. Changing society's attitudes towards the physically and mentally disabled. In J. Stubbins (Ed.), Social and psychological aspects of disability (pp. 269-278). University Park Press.

Banse, R., Seise, J., \& Zerbes, N. (2001). Implicit attitudes towards homosexuality: Reliability, validity, and controllability of the IAT. Zeitschrift fur Experimentelle Psychologie, 48, 145-160. https:// doi.org/10.1026//0949-3946.48.2.145

Brzeziński, J. (2012). Metodologia badań psychologicznych [Methodology of psychological research]. PWN.

Chaiken, S., \& Trope, Y. (1999). Dual process theories in social cognition. Guilford Press.

Chen, S., Ma, L., \& Xin-Zhang, J. (2011). Chinese undergraduates' explicit and implicit attitudes toward persons with disabilities. Rehabilitation Counseling Bulletin, 55, 38-45. https://doi.org/10.1177\%2F0034355211410705

Ćwirynkało, K. (2010). Pełnosprawni uczniowie wobec swoich rówieśników z niepełnosprawnością. Niepetnosprawność, 3, 93-106. https://doi.org/10.15633/9788374385077.12

Damasio, A. (2010). Self comes to mind: Constructing the conscious mind. Pantheon.

Fazio, R. H., Sanbonmatsu, D. M, Powell, M. C., \& Kardes, F. M. (1986). On the automatic activation of attitudes. Journal of Personality and Social Psychology, 50(2), 229-238. https://doi.org/10.1037/0022-3514.50.2.229

Festinger, L. (2007). Teoria Dysonansu Poznawczego [Cognitive Dissonance Theory]. Biblioteka Klasyków Psychologii.

Foroni, F., \& Bel-Bahar, T. (2010). Picture-IAT versus Word-IAT: Level of stimulus representation influences the IAT. European Journal of Social Psychology, 40, 321-337. https://doi.org/10.1002/ejsp.626

Greenwald, A. G., \& Banaji, M. R. (1996). Utajone poznanie społeczne: postawy, wartościowanie siebie i stereotypy [Implicit social cognition: Attitudes, self-evaluation, and stereotypes]. Przeglad Psychologiczny, 38, 11-48.

Greenwald, A. G., \& Farnham, S. D. (2000). Using the implicit association test to measure self-esteem and self-concept. Journal of Personality and Social Psychology, 79, 1022-1038. https://doi.org/10.1037/0022-3514.79.6.1022

Greenwald, A. G., McGhee, D. E., \& Schwartz, J. L. K. (1998). Measuring individual differences in implicit cognition: The Implicit Association Test. Journal of Personality and Social Psychology, 74, 1464-1480. https://doi.org/10.1037/0022-3514.74.6.1464

Imbir, K. (2018). Dwa systemy emocji i ich konsekwencje dla procesów poznawczych [Two systems of emotions and their consequences for cognitive procceses]. Wydawnictwo UW. 
Jarymowicz, M. (2006). O przejawach faworyzowania swoich względem obcych i rzekomej nieuchronności zjawiska [On manifestations of favoring oneself over strangers and the alleged inevitability of the phenomenon]. Instytut Psychologii PAN.

Kahneman, D. (2011). Thinking, fast and slow. Farrar, Straus, Giroux.

Kowalik, S. (1999). Psychospołeczne podstawy rehabilitacji osób niepetnosprawnych [Psychosocial basics of rehabilitation of disabled persons]. Śląsk.

Kowalik, S. (2007). Psychologia rehabilitacji [Psychology of rehabilitation]. Wydawnictwo Akademickie i Profesjonalne.

Kurtek, P. (2018). The Conditional Respect for Persons with Disabilities Questionnaire (CRPD-Q). Roczniki Psychologiczne, 4, 327-344. http://doi.org/10.18290/rpsych.2018.21.4-3

Larkowa, H. (1980). Postawy społeczne wobec osób z odchyleniami od normy. In A. Hulek (Ed.), Pedagogika rewalidacyjna [Rehabilitation pedagogy] (pp. 478-491). PWN.

Larsen, J. T. (2001). Can people feel happy and sad at the same time? Journal of Personality and Social Psychology, 81(4), 684-696. https://doi.org/10.1037//0022-3514.81.4.684

LeDoux, J. (1996/2000). Mózg emocjonalny [Emotional brain]. Media Rodzina.

Maison, D. (2004). Utajone postawy konsumenckie. Analiza możliwości wykorzystania metody IAT [Latent attitudes of consumers. Analysis of the possibilities of using the IAT method]. Gdańskie Wydawnictwo Psychologiczne.

Maison, D., Greenwald, A. G., \& Bruin, R. (2004). Predictive validity of the Implicit Association Test in studies on brands, consumer attitudes, and behavior. Journal of Consumer Psychology, 14, 405-415. https://doi.org/10.1207/s15327663jcp1404_9

Minczakiewicz, E. (1996). Postawy nauczycieli i uczniów szkół powszechnych wobec dzieci niepełnosprawnych umysłowo [Attitudes of primary teachers and pupils towards mentally disabled children]. In W. Dykcik (Ed.), Społeczeństwo wobec autonomii osób niepetnosprawnych [Attitude of the society towards the autonomy of disabled people] (pp. 131-144). Wydawnictwo Naukowe UAM.

Nowak, K. (2015). Postawy młodzieży wobec osób niepełnosprawnych ruchowo [Attitudes of youth towards physically disabled people]. Annales Universitatis Mariae Curie-Skłodowska, 28 (Sectio J), 67-81. https://10.17951/j.2015.28.1.67

Office of the Government Plenipotentiary for Disabled People (2021). Badanie aktywności ekonomicznej ludności [Survey of the population's economic activity] (January 13, 2021). http://niepelnosprawni.gov.pl/index.php?c=page\&id=78\&print $=1$

Pruett, S. R., \& Chan, F. (2006). The development and psychometric validation of the Disability Attitude Implicit Association Test. Rehabilitation Psychology, 51, 202-213. https://doi.org/10.1037/0090-5550.51.3.202

Reykowski, J. (1990). Ukryte założenia normatywne jako osiowy składnik mentalności [Implicit normative assumptions as the pivotal component of mentality]. In J. Reykowski, K. Skarżyńska, \& M. Ziółkowski (Eds.), Orientacje społeczne jako element mentalności [Social orientations as an element of mentality] (pp. 11-52). Nakom.

Rudman, L. A., Feinberg, J. M., \& Fairchild, K. (2002). Minority members' implicit attitudes: Ingroup bias as a function of group status. Social Cognition, 20, 294-320. https://doi.org/10.1521/soco.20.4.294.19908

Sękowski, A. (2001). Tendencje integracyjne a postawy wobec osób niepełnosprawnych. In Z. Palak (Ed.), Pedagogika specjalna $w$ reformowanym ustroju edukacyjnym [Special education in a reformed educational system] (pp. 135-147). Wydawnictwo UMCS. 
Sękowski, A., \& Witkowska, B. (2002). W kierunku typologii uwarunkowań postaw wobec osób niepełnosprawnych [Towards a typology of determinants of attitudes to disabled persons]. Roczniki Psychologiczne, 5, 129-144.

Siegert, R. J., \& Taylor, W. J. (2004). Theoretical aspects of goal setting and motivation in rehabilitation. Disability and Rehabilitation, 26, 1-8. https://doi.org/10.1080/09638280410001644932

Speck, O. (2015). Menschen mit geistiger Behinderung. Ein Lehrbuch zur Erziehung und Bildung [Persons with intellectual disabilities. Handbook for educational purposes]. Reinhardt Verlag.

Szelenberger, W. (2000). Potencjały wywołane [Evoked potentials]. Elmiko.

Thomas, A., Doyle, A., \& Daly, V. (2007). Implementation of a computer based Implicit Association Test as a measure of attitudes toward individuals with disabilities. Journal of Rehabilitation, 73, 3-14. https://doi.org/10.1177\%2F0034355211403008

Vaughn, D. E., Thomas, A., \& Doyle, A. L. (2011). The Multiple Disability Implicit Association Test: Psychometric analysis of a Multiple Administration IAT Measure. Rehabilitation Counseling Bulletin, 54, 223-235. https://doi.org/10.1177\%2F0034355211403008

Whitfiled, M., \& Jordan, C. H. (2009). Mutual influence of implicit and explicit attitudes. Journal of Experimental Social Psychology, 45, 748-759. https://doi.org/10.1016/j.jesp.2009.04.006

Wilson, T. D., Lindsey, S., \& Schooler, T. Y. (2000). A model of dual attitudes. Psychological Review, 107, 101-126. https://doi.org/10.1037/0033-295X.107.1.101

Wittenbrink, B., Judd, Ch. M., \& Park, B. (1997). Evidence for racial prejudice at the implicit level and its relationship with questionnaire measure. Journal of Personality and Social Psychology, $72,262-274$.

Wojciszke, B. (2005). Postawy i ich zmiana [Attitudes and their change]. In J. Strelau (Ed.), Psychologia. Podręcznik akademicki. Jednostka w społeczeństwie i elementy psychologii stosowanej (pp. 79-106). Gdańskie Wydawnictwo Psychologiczne.

Wyczesany, J., \& Gajdzica, Z. (2006). Uwarunkowania edukacji i rehabilitacji uczniów o specjalnych potrzebach $w$ rozwoju [Determinants of education and rehabilitation of school students with special developmental needs]. Wydawnictwo Naukowe Akademii Pedagogicznej.

Zasępa, E. (1998). Postawy społeczne wobec osób niepełnosprawnych [Social attitudes toward disabled persons]. Roczniki Pedagogiki Specjalnej, 9, 278-286. 